\title{
KARAKTERISTIK PENDERITA OTITIS MEDIA SUPURATIF KRONIK RAWAT JALAN DI RSUD. DR. PIRNGADI KOTA MEDAN TAHUN 2014
}

\author{
Elny Lorensi Silalahi \\ Jurusan Keperawatan Poltekkes Kemenkes Medan
}

\begin{abstract}
Abstrak
Otitis Media Supuratif Kronis (OMSK) merupakan penyakit infeksi telinga tengah dan sangat sering terjadi di Negara berkembang.Beban dunia akibat OMSK melibatkan 65 - 330 juta orang terutama di negara berkembang, dimana 39-200 juta orang (60\%) menderita penurunan fungsi pendengaran secara signifikan. Di Indonesia angka morbiditas THT sebesar 38,6\%.Diperkirakan terdapat 31 juta kasus baru OMSK per tahun, dengan 22,6\% pada anak-anak berusia $<5$ tahun.Penelitian merupakan penelitian Deskriptifdengan jumlah sampel 28 responden. Hasil penelitian ini menunjukkan bahwa mayoritas responden yang terkena Otitis Media supuratif kronik berdasarkan umur yaitu umur 61-70 tahun sebanyak 16 responden (57,14\%), jenis kelamin laki-laki yaitu sebanyak 22 responden (78,57\%), pendidikan SD yaitu sebanyak 13 responden (46 \%), bekerja sebagai wiraswasta sebanyak 13 responden (46 \%) dan keluhan telinga berair sebanyak 13 orang (46,46\%).
\end{abstract}

Kata kunci : Otitis Media Supratif Kronis (OMSK)

\section{PENDAHULUAN}

Otitis media supuratif kronik adalah suatu radang kronis telinga tengah dengan perforasi membran timpani dan riwayat keluarnya sekret dari telinga (ottorhea) lebih dari 2 bulan, baik terus menerus atau hilang timbul. Sekret mungkin encer atau kental, bening atau berupa nanah. (Soepardi, 2007).

Otitis Media Supuratif Kronis (OMSK) merupakan penyakit infeksi telinga tengah dan sangat sering terjadi di Negara berkembang. Angka kejadian OMSK di negara berkembang sangat tinggi dibandingkan dengan Negara maju. Hal ini disebabkan oleh faktor higiene yang kurang, faktor sosioekonomi, gizi yang rendah, kepadatan penduduk, serta masih adanya kesalahpahaman masyarakat terhadap penyakit ini sehingga mereka tidak berobat sampai tuntas (Nursiah, 2003).

Beban dunia akibat OMSK melibatkan 65 - 330 juta orang terutama di negara berkembang, dimana 39-200 juta orang (60\%) menderita penurunan fungsi pendengaran secara signifikan. Di India, dilaporkan terdapat 17,4\% penderita dengan otitis media kronis dari seluruh penderita yang berobat ke salah satu klinik THT, 15\% diantaranya dijumpai kolesteatoma, dan 5\% mengalami komplikasi. Survei Nasional Kesehatan Indra Penglihatan dan Pendengaran terakhir di delapan provinsi Indonesia menunjukkan angka morbiditas THT sebesar 38,6\%. Diperkirakan terdapat 31 juta kasus baru OMSK per tahun, dengan 22,6\% pada anak-anak berusia $<5$ tahun (Harry, 2013).

Beberapa faktor yang dapat menyebabkan otitis media akut menjadi otitis media kronis yaitu terapi yang terlambat diberikan, terapi tidak adekuat, virulensi kuman yang tinggi, daya tahan tubuh yang rendah (gizi buruk) atau hygiene buruk. (Djaafar ZA, 2008). Gejala otitis media supuratif kronis antara lain otorrhoe yang bersifat purulen atau mukoid, terjadi gangguan pendengaran, otalgia, tinitus, rasa penuh di telinga dan vertigo. OMSK dapat menyebabkan gangguan pendengaran sehingga menimbulkan dampak yang serius terutama bagi anakanak, karena dapat menimbulkan pengaruh jangka panjang pada komunikasi anak, perkembangan bahasa, proses pendengaran, psikososial dan perkembangan kognitif serta kemajuan pendidikan. Komplikasi intra kranial yang serius lebih sering terlihat pada eksaserbasi akut dari OMSK berhubungan dengan kolesteatom seperti abses ekstradural, abses subdural, tromboflebitis, meningitis, abses otak dan hidrosefalus otitis (Soetjipto D, 2007).

Penelitian Harry, dkk (2013) di RSUP H. Adam Malik Medan tentang profil penderita OMSK tipe bahaya pada umumnya terhadap 119 penderita dari tahun 20062010. Sekitar 28,57\% penderita dijumpai pada tahun 2010, sekitar 31,93\% terjadi pada usia 11 - 20 tahun, sekitar 53,78\% laki-laki, dan sekitar 38,66\% pada telinga kanan. Sebanyak $68,91 \%$ terjadi akibat riwayat otitis media berulang dan 61,34\% dengan keluhan utama telinga berair. Gejala dan tanda klinis yang sering terjadi adalah telinga berair $(76,47 \%)$ dan perforasi membran timpani $(74,79 \%)$, baik perforasi atik $(0,84 \%)$, marginal $(1,68 \%)$, subtotal (23,53\%), dan total (48,74\%). Gangguan pendengaran terbanyak adalah tuli konduktif (58,82\%). Pada foto proyeksi Schuller, 62,18\% dijumpai gambaran mastoiditis kronis dengan kolesteatoma. Dari hasil kultur dijumpai 21,01\% Pseudomonas aeruginosa. 86,55\% terjadi komplikasi mastoiditis. Hasil penelitian ini menyimpulkan bahwaprofil penderita OMSK tipe bahaya. 
Di Sumatera Utara tepatnya di RSUD.Dr. Pirngadi Kota Medan pada tahun 2012 jumlah pasien Otitis media supuratif kronik yaitu sejumlah 84 orang, tahun 2013, sejumlah 83 orang dan tahun 2014 sejumlah 88 orang. Dari data diatas menunjukkan terjadi kenaikan terhadap jumlah pasien yang menjalani pemeriksaan di poli THT RSUD.Dr. Pirngadi Kota Medan (Rekam Medik RSUD.Dr.Pirngadi, 2014).

\section{METODE PENELITIAN}

Penelitian merupakan penelitian Deskriptif. Penelitian akan dilaksanakan di Rumah Sakit Umum Daerah Dr.Pirngadi Kota Medan akan dilaksanakan penelitian pada bulan Juli- Oktober 2014. Cara pengambilan sampel dalam penelitian ini adalah dengan cara total sampling yaitu berjumlah 28 orang.

\section{HASIL PENELITIAN}

Tabel 4. 1 Distribusi Frekuensi Karakteristik penderita Otitis Media Supuratif Kronik Rawat jalan di RSUD.Dr.Pirngadi Kota Medan berdasarkan umur Tahun 2014

\begin{tabular}{ccc}
\hline Umur & f & \% \\
\hline >41-50Tahun & 1 & 3,57 \\
51-60 Tahun & 10 & 35,72 \\
61-70 Tahun & 16 & 57,14 \\
>70 Tahun & 1 & 3,57 \\
\hline Jumlah & $\mathbf{2 8}$ & $\mathbf{1 0 0}$ \\
\hline
\end{tabular}

Berdasarkan tabeldapat diketahui bahwa manyoritas penderitaOMSK yang berobat ke RSUD Dr Pirngadi Medan berada pada kelompok umur 61-70 tahun, yaitu sebanyak 16 responden (57,14\%).

Tabel 4. 2 Distribusi Frekuensi Karakteristik penderita Otitis Media Supuratif Kronik Rawat jalan di RSUD. Dr. Pirngadi Kota Medan berdasarkan Jenis Kelamin Tahun 2014

\begin{tabular}{ccc}
\hline Jenis Kelamin & F & \% \\
\hline Laki-laki & 22 & 78,57 \\
Perempuan & 6 & 21,43 \\
\hline Jumlah & $\mathbf{2 8}$ & $\mathbf{1 0 0}$ \\
\hline
\end{tabular}

Berdasarkan tabel diatas dapat diketahui bahwa bahwa mayoritas penderita OMSK yang berobat ke RSUD Dr Pirngadi Medan berjenis kelamin Laki-laki, yaitu sebanyak, 22 responden $(78,57 \%)$

Tabel 4. 3 Distribusi Frekuensi Karakteristik penderita Otitis Media Supuratif Kronik Rawat jalan di RSUD.Dr.Pirngadi Kota Medan berdasarkan Pendidikan Tahun 2014

\begin{tabular}{ccc}
\hline Pendidikan & f & \% \\
\hline SD & 13 & $46 \%$ \\
SMP & 8 & $28 \%$ \\
SMA & 5 & $18.86 \%$ \\
PT & 2 & $7.14 \%$ \\
\hline Jumlah & $\mathbf{2 8}$ & $\mathbf{1 0 0 \%}$ \\
\hline
\end{tabular}

Berdasarkan tabel dapat diketahui bahwa manyoritas penderita OMSK yang berobat ke RSUD Dr Pirngadi Medan hanya berpendidikan SD, yaitu sebanyak 13 responden (46\%).

Tabel 4. 4 Distribusi Frekuensi Karakteristik penderita Otitis Media Supuratif Kronik Rawat jalan di RSUD.Dr.Pirngadi Kota Medan berdasarkan Pekerjaan Tahun 2014

\begin{tabular}{lcc}
\hline \multicolumn{1}{c}{ Pekerjaan } & f & \% \\
\hline PNS & 8 & $28 \%$ \\
Wiraswasta & 13 & $46 \%$ \\
Petani & 5 & $18.86 \%$ \\
IRT & 2 & $7.14 \%$ \\
\hline Jumlah & $\mathbf{2 8}$ & $\mathbf{1 0 0 \%}$ \\
\hline
\end{tabular}

Berdasarkan tabel dapat diketahui bahwa manyoritas penderita OMSK yang berobat ke RSUD Dr Pirngadi Medan bekerja sebagai wiraswasta, yaitu sebanyak 13 responden (46\%).

Tabel 4. 5 Distribusi Frekuensi Karakteristik penderita Otitis Media Supuratif Kronik Rawat jalan di RSUD.Dr.Pirngadi Kota Medan berdasarkan keluhan Utama Tahun 2014

\begin{tabular}{ccc}
\hline Keluhan Utama & f & \% \\
\hline Telinga berair & 13 & $46.46 \%$ \\
\hline Gangguan pendengaran & 3 & $10.7 \%$ \\
\hline Nyeri & 10 & $35.7 \%$ \\
\hline Vertigo & 2 & $7.14 \%$ \\
\hline Jumlah & $\mathbf{2 8}$ & $\mathbf{1 0 0 \%}$ \\
\hline
\end{tabular}

Berdasarkan tabel dapat diketahui bahwa manyoritas penderita OMSK yang berobat ke RSUD Dr Pirngadi Medan mengeluh telinga berair, sebanyak 13 responden $(46,46 \%)$.

\section{PEMBAHASAN}

\section{Umur}

Hasil penelitian menunjukkan bahwa berdasarkan umur merupakan gambaran karakteristik penyebab terjadinya Otitis Media supuratif kronik, yakni mayoritas responden yang menderita Otitis Media supuratif kronik dengan umur 61 s/d 70 tahun berjumlah 16 responden (57,14\%). Hal ini terjadi karena semakin bertambahnya usia, semakin tinggi resiko terkena berbagai jenis penyakit. Setelah berusia 55 Tahun, resiko berlipat ganda setiap kurun waktu sepuluh tahun. Dua pertiga dari semua serangan Otitis Media supuratif kronik terjadi pada orang berusia di atas 65 tahun (Vita Health, 2006).

Lanjut usia merupakan kelompok yang banyak menderita berbagai penyakit. Hal ini disebabkan karena pada lanjut usia banyak mangalami penuruan fungsi organ tubuh yang tidak dapat bekerja secara normal.

2. Jenis Kelamin

Penelitian menunjukkan bahwa Jenis Kelamin merupakan gambaran karakteristik penyebab terjadinya Otitis Media supuratif kronik , yakni lebih dari 50\% responden yang menderita Otitis Media supuratif kronik 
berjenis kelamin laki-laki dengan jumlah 22 responden (78\%). Hal ini terjadi karena gaya hidup laki-laki banyak yang beresiko terkena berbagai jenis penyakit seperti Otitis Media supuratif kronik.

Penyakit Otitis Media supuratif kronik tidak membedakan jenis kelamin namun penyakit Otitis Media supuratif kronik lebih beresiko terjadi pada pria dibanding wanita yaitu 1,25\% lebih tinggi dari wanita. (Vita Health, 2006).

Stress meningkatkan aktivitas saraf simpati. Peningkatan tekanan rongga kavum timpani apa bila berkepanjangan dapat berakibat akan memicu terjadinya Otitis Media supuratif kronik. Dalam hal ini laki-laki merupakan punggung pencari nafkah sehingga beban pikiran dapat menyebabkan gangguan fisik maupun psikis, adanya hormonal adrenalin yang dihasilkan sebagai reaksi tubuh terhadap stress bila berlebihan dan berlangsung lama akan menyebabkan reaksi dari organ tubuh lainnya (Vita Health, 2006).

Peneliti Harry, dkk (2013) juga mendapatkan insidensi yang sama bahwa jumlah penderita OMSK di RSUP H Adam Malik, laki-laki (73.9\%) lebih banyak dibandingkan wanita (26.1\%). Hal ini disebabkan oleh pekerjaan laki-laki yang lebih sering dilaksanakan di luar ruangan sehingga lebih mudah dan sering terinfeksi dengan kontaminan lingkungan

3. Pendidikan

Penelitian menunjukkan bahwa pendidikan juga merupakan gambaran karakteristik penyebab terjadinya Otitis Media Supuratif Kronik, yakni mayoritas dari penderita Otitis Media Supuratif Kronik adalah berpendidikan SD sebanyak 13 orang (46 \%), Penyakit Otitis Media supuratif kronik tidak membedakan pendidikan namun penyakit Otitis Media supuratif kronik lebih beresiko terjadi pada orang yang berpendidikan lebih rendah. Hal ini karena orang yang berpendidikan lebih rendah pengetahuan tentang resiko terjadi penyakit ini dan penyebab terjadinya sangat kurang (Vita Health, 2006).

4. Pekerjaan

Penelitian menunjukkan bahwa pekerjaan juga merupakan gambaran karakteristik penyebab terjadinya Otitis Media Supuratif Kronik , yakni mayoritas responden mempunyai pekerjaan sebagai wiraswasta sebanyak 13 orang (46\%), sebagai PNS sebanyak 8 orang (28\%), sebagai Petani sebanyak 5 orang (18.86 \%), dan yang mempunyai pekerjaan sebagai Ibu rumah tangga yaitu 2 orang (7.14\%).

\section{Keluhan Utama}

Penelitian menunjukkan bahwa pendidikan juga merupakan gambaran karakteristik penyebab terjadinya Otitis Media Supuratif Kronik, yakni mayoritas dari penderita Otitis Media Supuratif Kronik bahwa dari 28 responden yang diteliti mayoritas responden mempunyai keluhan telinga berair sebanyak 13 orang (46.46 \%), gangguan pendengaran sebanyak 3 orang (10.7\%), nyeri sebanyak 10 orang (35.7\%), vertigo yaitu 2 orang (7.14 $\%)$.

Sejalan dengan penelitian Harry,dkk (2013) tentang profil penderita OMSK yaitu sebanyak 73 penderita mengeluhkantelinga berair $(61,34 \%)$. Telinga tersumbat palingsedikit dikeluhkan penderita (0,84\%). Telinga kananpaling banyak terkena (46; 38,66\%) proporsi terendahpada kedua telinga (28,57\%).Gejala klinis yang palingbanyak adalah telinga berair $(91 ; 76,47 \%)$ dan palingsedikit telinga gatal (8; 6,72\%).

\section{KESIMPULAN}

Mayoritas responden yang terkena Otitis Media supuratif kronik berdasarkan umur yaitu umur 61-70 tahun sebanyak 16 responden (57,14\%), jenis kelamin laki-laki yaitu sebanyak 22 responden (78,57\%), pendidikan SD yaitu sebanyak 13 responden (46\%), bekerja sebagai wiraswasta sebanyak 13 responden (46 \%) dan keluhan telinga berair sebanyak 13 orang (46.46\%).

\section{SARAN}

Kepada pihak RSUD.Dr.Pirngadi Kota Medan khususnya di Poli THTmemberikan pendidikan kesehatan tentang pencegahan dan pengobatan OMSK terhadap kelompok-kelompok yang menderita OMSK dan memiliki resiko menderita OMSK sesuai dengan karakteristik pasien yang datang kepelayanan kesehatan THT.

\section{REFERENSI}

Alimul, A, 2006. Riset Keperawatan dan Teknik Penulisan Imiah. Salemba Medika : Jakarta.

Anies, 2006. Waspada Ancaman Penyakit Tidak Menular, Elex Media Komputindo, Jakarta.

Arikunto, S, 2010. Praktek Prosedur Penelitian Suatu Pendekatan. Edisi S. Rineka Cipta : Jakarta.

Brunner dan Suddart, 2008. Keperawatan Medikal Bedah, Edisi 8, Vol. 2, EGC. Jakarta.

Damaiyanti, M, 2008. Komunikasi Terapeutik dalam PraktikKeperawatan Edisi I. Bandung: Refika Aditama,.

Elizabeth, J, Corwin.2006. Buku saku Fatofisiologi. Jakarta:EGC.

Harry, dkk. Profil Penderita Otitis Media Supuratif Kronis. Jurnal Kesehatan Masyarakat Nasional Vol. 7, No. 12, Juli 2013

Harry, dkk.Gambaran Pasien Otitis Media Supuratif Kronik (OMSK) di RSUP H. Adam Malik Medan.E-Journal FK USU Vol 1 No 1, 2013

Nasir, A, 2009. Komunikasi Dalam Keperawatan Teori dan, Aplikasi, Salemba Medika : Jakarta.

Notoatmodjo, S, 2010. Metode Penelitian Kesehatan, Edisi Revisi. Rineka Cipta : Jakarta

Nursalam, 2010. Konsep dan Penerapan Ilmu Keperawatan. Salemba Medika : Jakarta.

Nursiah, S. 2003. Pola Kuman Aerob Penyebab OMSK Dan Kepekaan Terhadap Beberapa Antibiotika Di Bagian THT FK USU/RSUP H Adam Malik Medan.http//:library.usu.ac.id/download/fk/thtsiti\%20nursiah. pdf 
Doenges, Marlynn, E .2008.Rencana Asuhan Keperawatan, Edisi III, EGC, Jakarta.

Peter, M, Nowschhenson. 2008. Segi Praktis Ilmu Bedah untuk Pemula. Bina Aksara Jakarta
Soepardi, Iskandar $\mathrm{N}$ et al. 2007. Buku ajar Ilmu Kesehatan Telinga, Hidung, Tenggorokan, Kepala, dan Leher. Jakarta: Balai Penerbit FK UI 